\title{
農村住民の消化器疾患について
}

\section{Gastroenteric diseases in rural people}

\author{
京都府立医科大学衞生学教室（主任 額田粲教授） \\ 細 見 義 明 \\ Yoshiaki Hosomi \\ Department of Hygiene, Kyoto Prefectural School of Medicine \\ (Director: Prof. A. Nukada)
}

\section{はしがき}

著者らはさきに某県下の高校教職員, 県庁職員ならび に交通関係従業員について消化器疾患の調査を行い, 消 化器疾患の症状が職場環境によつて非常飞相違すること を報告した。以上の対象ふいずれも都市の住民であるの で, 今回注近代的産業上经直接的関係のうすい農村の住 民について同様の調查を行つた。

\section{調查方法}

対象法京都府北部海岸飞ある農村である。調查票柱 「高校教職員注打る消化器疾患について」に使用した もの上，添添同形式のものを使用し，乙れに昭和34年10 月現在の消化器疾患についての自覚症状㧠よび既往症を 記入吃しぬた。保健所を通じ配布した調查票は 3,000 枚 に抢よえだが，その中 2,406 枚が回収できた。しかし集 計には前報の被検者の年略学考慮し, 満20才より59才ま での男女1,244 名の分の文用いた。气の内訳注農業従
事者は男子 422名女子 497名で，農業に従事しないその 他の農村住民は．男子 193名女子 132名である。その他 の農村住民とは, 部策従事者安除外した住民全部で, 商 業・工業・給料生活者・自由業・無職が含まれている。

\section{調 査成 績}

\section{1. 自覚症状の発現率}

第 1 表は職種別年齢別有症率である。ここに有症者と 法消化器疾患の自覚症状のうち, 胃の不調感・胃痛腹痛 ・腹部膨満・胸や行・げつぷ・呕気・酸性噯気・胸につ かえるなどのうち，いずれかの一つでも自覚症状を訴え た者である。総数として有症率济, 男子では榓業従事者 $34.1 \%$ その他の農村住民 $37.3 \%$ ，女子では農業従事者 22

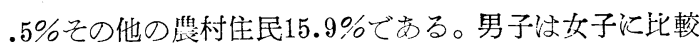
し自覚症状の訴元が多い。

男女己も有症率には有意の年齢差は認められないが, 男子農村住民飞扮いては，有意ではないが 30 才代に高い 傾向が認好られる。

第 1 表 職種别年齢别有症率

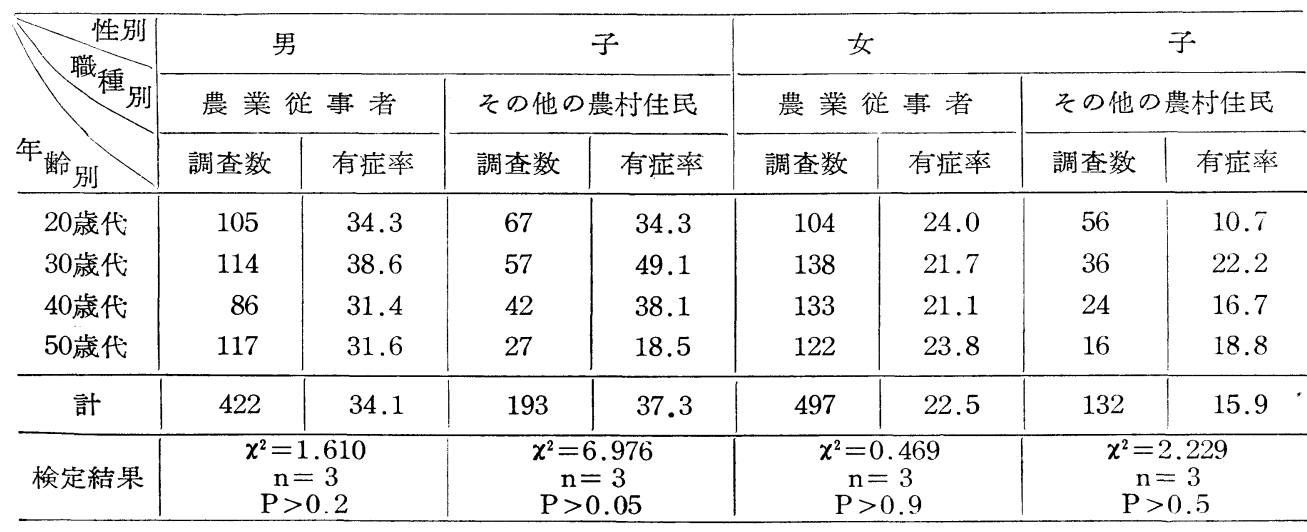




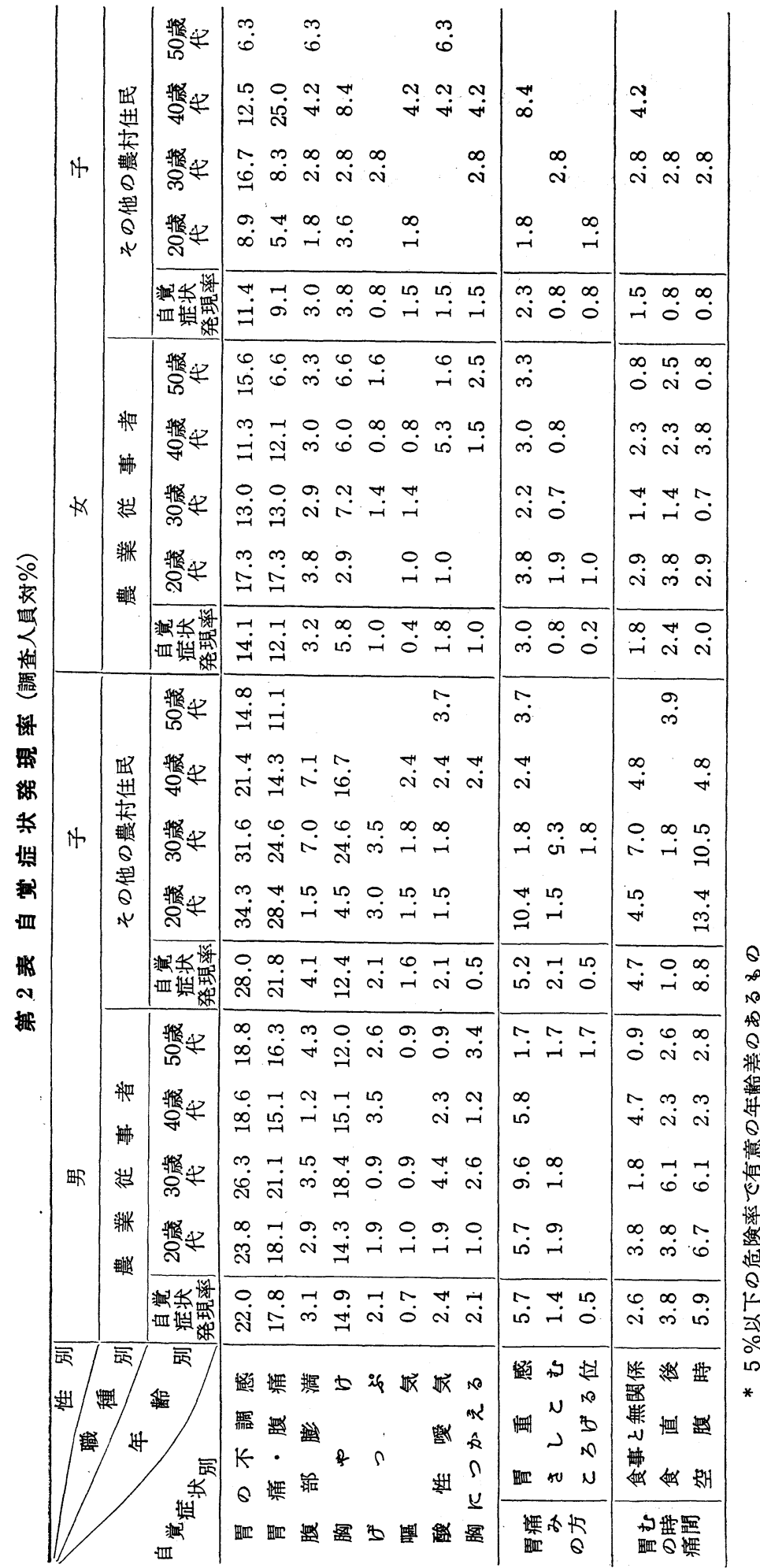

以上の結果を前報までの他の職業と 比較してみると, 男子農村住民の有症 率注，高校教職員 ${ }^{12}$ ， 県庁職員 ${ }^{21}$ ，石 油精製工員 ${ }^{3)}$ と同程度で，交通関係従

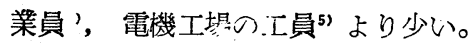
又女子では, バス車掌・高校教職沜・ 県庁職員などよりも有症率は低い傾向 が認められる。

第 2 表は自覚症状の内容の調查結果 である。農村住民では男女とも，胃の 不調感・胃痛腹痛が自覚症状の過半数 をしめ, これらについで胸やけが多 く, 腹がはる・すつぱい水があがる・ げつぷ・胸につかえる・はきけ等の訴 えは少い。との傾向は前報までの結果 と全く同様である。

以上の順位には, 年柃性別に関係が なく $x^{2}$ 検定の結果も有意の差とは認 められなかつた。

又, 胃の痛及の大部分は胃重感で, さしこむ痛み・ころげる立の痛及は少 いととも，高校教職員・交通関係従業 員の場合と全く同じ傾向である。胆道 疾患と密接な関係があると推定される 「ころげる位」の激痛は, 本調查では 農業従事者でも農業以外の職䎲ついて る者でも, 男子 $0.5 \%$ 女子 $0.2 \sim 0.8$ \%程度に過ぎない。乙れの值は前報の 交通関係従業員の場合とほ涪同率であ り, 櫎6) の東北地方の㖘村住民につい ての $5 \%$ という值にくらべると非常に 低い。

胃の痛さ時刻として蛙, 男子では空 腹時痛が最む多く, 女子ではこのょう な食事時間との関係㞲認められなかつ た。男子に打ける以上の結果深, 都市 に打ける交通関係従業員・石油工員・ 電機工員の場合と同様てある。

要するに農村に扔いては, 男子では 農業従事者の方が, 農亲に従事しない 者よりも自覚症状の訴えが少いが, 女 子では農業に従事している者の方が， 従事していない者よりも訴えが多い傾 向が認められた。 
第 3 表 職種年踰别有既往率

\begin{tabular}{|c|c|c|c|c|c|c|c|c|}
\hline \multirow{3}{*}{ 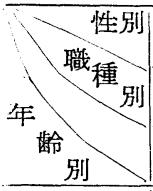 } & \multicolumn{2}{|c|}{ 男 } & \multicolumn{2}{|c|}{ 子 } & \multicolumn{2}{|c|}{ 女 } & \multicolumn{2}{|c|}{ 子 } \\
\hline & \multicolumn{2}{|c|}{ 農 業 䢨 事 者 } & \multicolumn{2}{|c|}{ その他の農村佳民 } & \multicolumn{2}{|c|}{ 農 業 従 事 者 } & \multicolumn{2}{|c|}{ その他の農村佳民 } \\
\hline & 調查数 & 有既往率 & 調查数 & 有既往率 & 調查数 & 有既往率 & 調查数 & 有既往率 \\
\hline 20歳代 & 105 & 14.3 & 67 & 31.3 & 104 & 10.6 & 56 & 14.3 \\
\hline .30歳代 & 114 & 24.6 & 57 & 26.3 & 138 & 24.6 & 36 & 25.0 \\
\hline .40歳代 & 86 & 38.4 & 42 & 23.8 & 133 & 16.5 & 24 & 33.3 \\
\hline 50歳代 & 117 & 29.1 & 27 & 33.3 & 122 & 21.3 & 16 & 31.3 \\
\hline 計 & 422 & 26.1 & 193 & 28.5 & 497 & 18.7 & 132 & 22.7 \\
\hline 検定結果 & \multicolumn{2}{|c|}{$\begin{array}{c}\chi^{2}=7.890 \\
n=3 \\
p<0.05\end{array}$} & \multicolumn{2}{|c|}{$\begin{array}{c}\chi^{2}=1.162 \\
n=3 \\
P>0.7\end{array}$} & \multicolumn{2}{|c|}{$\begin{array}{c}x^{2}=8.734 \\
n=3 \\
p<0.05\end{array}$} & \multicolumn{2}{|c|}{$\begin{array}{c}x^{2}=4.115 \\
n=3 \\
\mathrm{p}>0.2\end{array}$} \\
\hline
\end{tabular}

\section{一2、既往に䍜患した胃腸实患について}

第 3 表は職種別年齡別有既往率である。ここに有既往: 率とは, 既往に急性胃炎・慢性胃炎・胃瘃攣・十二指腸 潰瘍・胃搪張・胃下垂・虫垂炎・肝胆疾患のう5, w势 れか一つ以上の疾患に罹患したてとのある者の人数を， 調査人員に対する百分率としてあらわしたものである。

総数としては男子では, 農業従事者 $26.1 \%$ その他 28.5 \%，女子では農策従事者 $18.7 \%$ この他 $22.7 \%$ ，男女を 㵍わず前報までの都市の住民よりも有既往率が低い，と

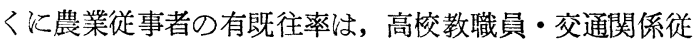
業員・石油工員に比較すると半分以下であり, 都市の住 民として注低心県庁職員・電機工員よりも更に低率であ る。又女子では，農業従事者前に述べょうに，その 他の農村住民にくらべ自覚症状の多いにも拘らず，既往 症は少い傾向がみられる。

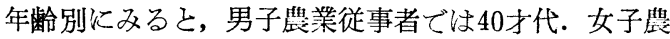
業従事者では 30 才代に有既往率は最む高く, これ以上の 年齢ではかえつて減少している。 $\chi^{2}$ 検定の結果, この年 齢差は $5 \%$ 以下の危険率で有意の相違と認められた。男 女とむ農業従事者以外では有意の年龄差牥認められなか つた。

第 4 表は既往症の内訳である。男子農業従事者では， 肝胆疾患（肝炎・黄疽・胆石症・胆の了炎を含む）が最 も多く, 第 2 位は胃痤攣，第 3 位は 虫垂炎になつてい 污。女子農業従事者でも, 肝胆疾患が最も多く, 第 2 位 㖞虫垂炎, 第 3 位胃痤卛の順になつている。農業従事者 以外では男女とも，第1 位虫垂炎，第 2 位肝胆疾患，第 : 3 位胃痤攀である。農業従事者屿前報の交通関係従業員 .・高校教職員・石油工員 と同様, 肝胆疾患が 非常に多 叹。農業従事者以外の男子では, 虫垂炎の既往歴が非常 せ高いが, 男子の農業従事者ならびそ女子では, 前報の
種々の職業にくらべ非常に罹患率が低い。

胃潰瘍の罹患率は, 男子では囦業従事者 $1.9 \%$, 農業 從事者以外 $3.1 \%$ 市るが, 女子では農業従事者では皆

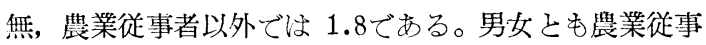
者以外では高く, 前報の交通関係従業員・高校教職員飞 近い罹患率を示しているぶ，農業従事者は男女とも低率 である。

十二指腸潰腸の 罹患率注, 男子では農業従事者 1.9 $\%$, 農業従事者以外では $1.6 \%$, 女子では農業従事者 $1.9 \%$ ，農業従事者以外では $1.8 \%$ あつた。男子では 交通関係従業員・高校教職員认くらべ低く, 石油工員・ 電機工員と洍济同率の值を示しているが，女子では，バ ス車掌・高校教職員にくらべ高いようである。

疾患別に年齢差を検討してみたが，第 4 表に示すよう 飞，40才代男子の農業従事者にとくに多い肝胆疾患を除 いては，5\%以下の仜険率で有意の年齢差を示している 疾病は認められなかつた。

\section{3. 既往症の有無と有症率との関係}

第 5 表は既往症の有る者とない者と飞分け，有症率の 程度を調べた結果である。交通関係従業員・高校教職員 ・斨庁職員・石油工員については, 既往症のある者では ない者にくらべ，2 倍以上の有症率を示しているが，男 子農村住民ではその差があまり著明に認められない。こ れは既往症のない者でも自覚症状の訴えが多いためであ る。とれに反し女子では, 前報の高校教職員・県庁職員 の場合と同様, 既往症のある場合には, ない者にくら べ, 湾涪 2 倍近くの有症率を示している。

第 5 表に示すように，有症率の年踰差快若年粭にやや 高い傾向が認わられるが，有意の差とは認められなかっ た。 


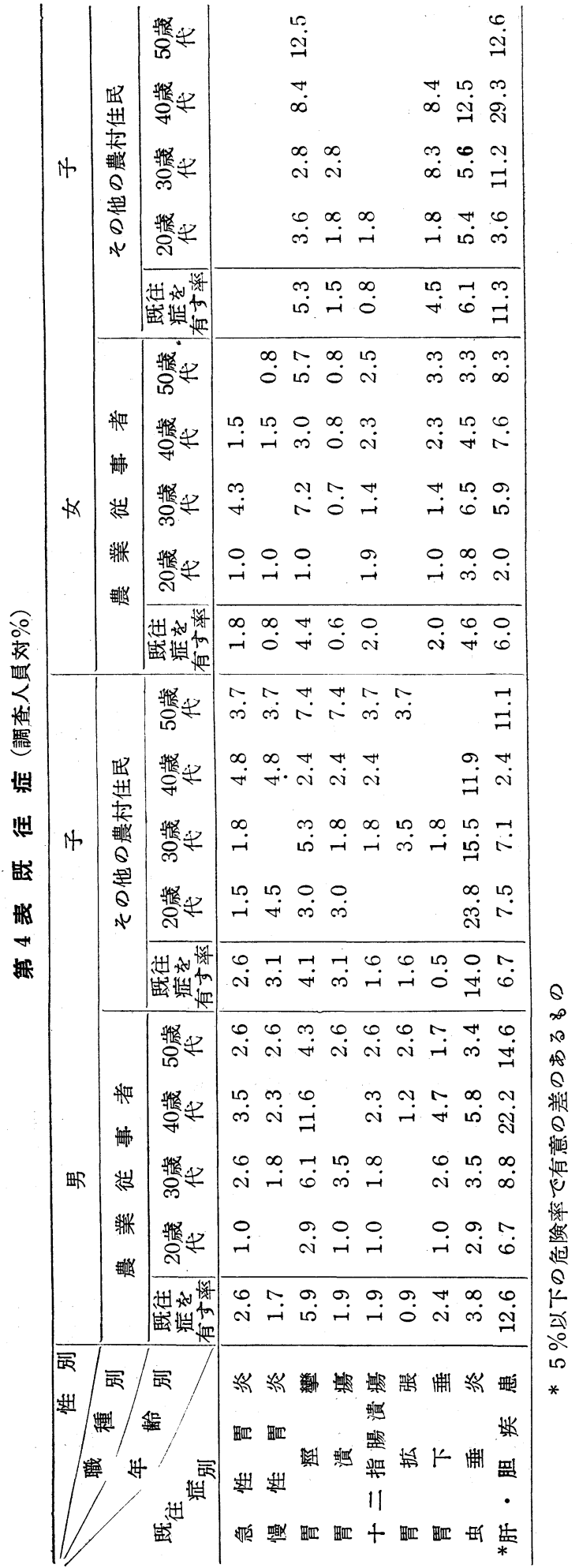

\section{考 察}

以上の結果を綜合すると，農村住民では消化器症状の 訴えが，都市の住民にくらべると少いと云い得る。消化 器症状の訴元洨精神身体医学的に往, 精神的身体的ス下 レス7-11) に大いに関係があるとすれば.ストレスの発生 要因が少い農村では, 都市にくらべ消化器症状の訴えも 少いのは当然であろう。

社会学的見地加農村と都市とを比較してみると,

第Iには，農村は都市にくらべ社会生活に対する不安 感と焦燥感が少い。

Nels Anderson ${ }^{12}$ の云うょうに農村心都市にくらべ刺 戟が少く, 対人関係も深く永続的で, 伝統慣例に縛られ ることが多い。又農村では血縁関係の結合が多く, その 交際は深く永続性があり, 都市涯ぞ坬立感は少い。

農村では，職業身分の変化ならびに居住の変動が少 々，都市に久られるような上昇沈澱作用もはるかに小さ い。農業従事している限り, 生活に対する安定感は都. 市にくらべて強い。之に反し都市では，オートメ化に伴 い, 生産力が一層に高度の知的水準を要請する。そして 結果として，知能の低いものはしりでけられる。てのよ 了な労㗢適応 ${ }^{13)}$ の問題は, 単純筋肉労働者法ど深刻であ. り, 将来の失業に対する絶えざる不安感を持ち, 焦燥傜 かられるこのような単純労働者は, 都市に打ける労働力 の大部分去占めているのである。

第 2 亿は農村は都市にくらべ欲求不満が少い。

農村に招ける労働は, 都市にくらべ前時代の労㗢であ る。近代的産業に怙ける労㗢にくらべると, 肉体的にも 時間的にも過重労働である。近代産業では, 経営と労働 の分離ならびに労働の分業化・細分化が行われるが，農 村ではこのようなととがない。そのため農村に抢ける労 働㤝, 意欲的・自主的であり, 労働の熟達と合理化その むのが，自己の生産性を高め，その生活意欲を満足させ ること役立つている。

このように都市労働者では, 科学的技術の発達により 心理的萢藤が多く，乙れが Stressor としての比重を益 从大きくさせている。都市と農村に扔ける消化器疾患の 罹患率の相違は，扮そらくその根底に扮いては，乙のよ うな両者間の社会的環境の相違にもこずくものである ろ。

\section{結 論}

京都府下某農村住民男子 615 名女子 629 名について, 消化器疾患に関する自覚症状招よび既往症を調查し, 次 
第 5 表 既往症の有無と有症率との関係

\begin{tabular}{|c|c|c|c|c|c|}
\hline \multirow{2}{*}{\multicolumn{2}{|c|}{ 性別 ${ }^{\text {年 }}$ 職 $\begin{array}{ll}\% \\
\text { 別 }\end{array}$}} & \multicolumn{2}{|c|}{ 既往症を有する者の有症率 } & \multicolumn{2}{|c|}{ 既往症のない者の有症率 } \\
\hline & & 農 & そ の 他 & 業 & の \\
\hline \multirow{4}{*}{ 男 } & 20 歳 代 & 60.0 & 42.9 & 31.1 & 30.4 \\
\hline & 30 歳 代 & 53.6 & 66.7 & 33.7 & 42.9 \\
\hline & 40 歳 代 & 30.3 & 30.0 & 32.1 & 40.6 \\
\hline & 50 歳 代: & 38.2 & 22.2 & 28.9 & 16.7 \\
\hline \multirow[t]{2}{*}{ 子 } & 計 & 42.7 & 43.6 & 31.4 & 34.8 \\
\hline & 検定結果 & $\begin{array}{c}\chi^{2}=5.507 \\
n=3 \\
P>0.1\end{array}$ & $\begin{array}{c}x^{2}=3.667 \\
n=3 \\
P>0.3\end{array}$ & $\begin{array}{c}\chi^{2}=0.477 \\
n=3 \\
P>0.9\end{array}$ & $\begin{array}{c}\chi^{2}=4.009 \\
\mathrm{n}=3 \\
\mathrm{P}>0.3\end{array}$ \\
\hline \multirow{4}{*}{ 女 } & 20 歳 代 & 36.4 & 37.5 & 22.6 & 6.3 \\
\hline & 30 歳 代 & 32.4 & 33.3 & 18.3 & 18.5 \\
\hline & 40 歳 代 & 40.9 & 25.0 & 17.1 & 12.5 \\
\hline & 50 歳 代 & 30.8 & 20.0 & 21.9 & 18.2 \\
\hline \multirow[t]{2}{*}{ 子 } & 計 & 34.4 & 30.0 & 19.8 & 11.8 \\
\hline & 検定結果 & $\begin{array}{c}\chi^{2}=0.596 \\
n=3 \\
P>0.8\end{array}$ & $\begin{array}{c}\chi^{2}=0.006 \\
n=3 \\
P>0.99\end{array}$ & $\begin{array}{c}\chi^{2}=1.386 \\
n=3 \\
P>0.7\end{array}$ & $\begin{array}{c}\chi^{2}=1.526 \\
n=3 \\
P>0.5\end{array}$ \\
\hline
\end{tabular}

の結果学得た。

1）他の職場に比へ，農村住民の自覚症状の訴えは少 く, とくに女子汶男子に比較し少い。自覚症状の過半数 䖪, 胃の不調感・胃痛腹痛で, この傾向仗他の職場と全 く同様である。胃痛は大部分胃重感に近く, とくに男子 農村住民では空腹時痛が多い。

2）既往症についても他の職場に比べ少く，岪業従事 者では最む少い。農業従事者では他の職場之同様肝胆疾 患が多いが，虫垂炎の罹患率注低い，又男子些村住民の

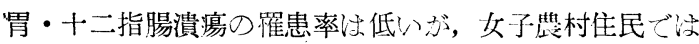
高い傾向にある。

3）男子㤟村住民では，他の職場飞比較し政往症のな い者でも自覚症状の訴えが多い傾向が認められるが，女 子では他の職場上同様，既往症のない者の有症率纺低 w。

4）堭村住民の消化器症状の訴えが少いのは，他の職 場飞比較し, 精神的身体的ストレスに上る消化器疾患在 誘発し難いふらである。

稿を終るに当り御指導御校閲を賜つた額田然教授に深 謝すると共に，資料の蒐集に御協力下さつた京都府網野 保健所菊池昭子所長ならびに同職員の方々に厚く御礼申
し上げます。な扣本論交の要旨は第30可日本得少:学会総 会に招いて発表した。

\section{参考交献}

1）細見：日本衛生学雑誌，14，2，98-105，1959.

2）細見·中島・小口：日本衛生学雑誌，15，5，1960.

3）額田・山口：第32回日本産業医学会にて発表，日 本衛生学雑誌掲載子定.

4）組見：日本衛生学雑誌，15，1，1960.

5) 佐藤 : 労災, 第 8 巻第 3 号, p. 40-47.

6) 椬：日本医事新報，No.1738，6-10，1957.

7) 松本·加藤：サイコ：ソマティックス，115-131, 1957

8) Weiss and English: Psychosomatic Medicine, 254-306, 1957.

9）田多井：精神身体医学講座，第 1 巻，心飞身体 上, $217-249$.

10）小坂：精神身体医学講座，第 3 巻，病気と心上， 203-220.

11) Harold, G. Wulff : Stress and Diseases p. 3652,1957

12）磯村：部市社会学，11，19，44, 昭和 30 .

13）暉峻: 精神身体医学啭座, 第 1 巻, 心飞身体上, $\mathrm{p}, 265-291$.

（受付：1960年 6 月 25 日） 